\title{
Eosinophil granule proteins expressed in ocular cicatricial pemphigoid
} Arnd Heiligenhaus, Jörg Schaller, Sabine Mauß, Susan Engelbrecht, James E Dutt,
C Stephen Foster, Klaus-Peter Steuhl

\begin{abstract}
Background-Blister formation and tissue damage in bullous pemphigoid have been attributed to the release of eosinophil granule proteins-namely, to eosinophil derived cationic protein (ECP) and major basic protein (MBP). In the present investigation these eosinophil granule proteins were studied in the conjunctiva of patients with ocular cicatricial pemphigoid (OCP).

Methods-Conjunctival biopsy specimens obtained from patients with subacute $(n=8)$ or chronic conjunctival disease $(n=13)$ were analysed histologically and immunohistochemically using antibodies directed against EG1 (stored and secreted ECP), EG2 (secreted ECP), MBP, CD45 (common leucocyte antigen), CD3 (pan T cell marker), and HLA-DR (class II antigen).
\end{abstract}

Results-Subepithelial mononuclear cells, mast cells, and neutrophils were detected in all specimens. The number of mononuclear cells, neutrophils, CD45+ cells, CD3+ cells, and the HLA-DR expression were significantly higher in the subacute than in the chronic disease group. Some eosinophils were found in specimens from five of eight patients with subacute OCP, but in none of the patients with chronic disease. The eosinophil granule proteins (ECP and MBP) were found in the epithelium and substantia propria in patients with subacute conjunctivitis.

Conclusions-Subepithelial cell infiltration in the conjunctiva greatly differs between subacute and chronic ocular cicatricial pemphigoid specimens. The findings suggest that eosinophil granule proteins may participate in tissue damage in acute phase of inflammation in OCP. (Br F Ophthalmol 1998;82:312-317)

Ocular cicatricial pemphigoid (OCP) is a rare disease leading to shrinkage of the conjunctiva. ${ }^{12}$ Conjunctival fibrosis may cause severe entropion, trichiasis, symblepharon formation, dry eye, and epithelial ulceration. ${ }^{13}$ Without treatment the cicatrising disease progresses in $75 \%$ of the patients, ${ }^{4}$ eventually resulting in blindness by complications to the cornea. The disease course may be chronic, subacute, or acute, with exacerbation of severe conjunctival inflammation. While systemic immunosuppression stops progression of cicatrisation in most patients, ${ }^{5-7}$ it fails in approximately $10 \%$ of them. Further investigation is required to characterise the pathogenetic steps of this disease more exactly.

There is compelling evidence that cicatricial pemphigoid is an autoimmune disease. Autoantibodies directed against antigens in the lamina lucida of the epithelial basement membrane have been demonstrated in genetically susceptible individuals. ${ }^{1289}$ Marked inflammatory cellular infiltrations in the epithelium and substantia propria are typically found during exacerbation. ${ }^{2}{ }^{10}$

It has been found that eosinophils, by their highly proinflammatory activity and the release of toxic products, contribute to the tissue damage in various inflammatory diseases, including ocular allergies and orbital inflammation. ${ }^{11-14}$ The four major proteins found in eosinophil granules and released upon eosinophil stimulation are eosinophil cationic protein (ECP), eosinophil protein $\mathrm{X} / \mathrm{eosinophil} \mathrm{derived} \mathrm{neuro-}$ toxin $(\mathrm{EPX} / \mathrm{EDN})$, major basic protein (MBP), and eosinophil peroxidase.

It has been shown recently that activated eosinophils and their granules contribute to the development of dermal lesions in bullous pemphigoid of the skin. ${ }^{15}$ While neutrophils and lymphocytes are abundant in OCP lesions, eosinophils are rarely detected by classic histological techniques even in the acute stage of disease. ${ }^{1617}$ However, eosinophils might not be found histologically after degranulation. In the present study we investigated the presence of eosinophils and their granule proteins by immunohistochemical techniques in cicatricial pemphigoid affecting the conjunctiva in an attempt to study the pathogenic role of eosinophils in this inflammatory disorder.

\section{Materials and methods}

PATIENTS

Twenty one patients with bilateral progressive OCP were enrolled in this study. The records and photographs of all patients were reviewed. Each patient's comprehensive medical history, including prior ocular surgery, and treatments with systemic immunosuppressive drugs were noted.

The diagnosis of cicatricial pemphigoid was based on clinical criteria published elsewhere. ${ }^{2}$ Progressive symblepharon formation, fornix foreshortening, and subconjunctival fibrosis were found in all patients. According to the Foster staging system, ${ }^{1}$ the patients had stage 3 disease. The inflammatory activity was graded on a scale of 0 to $4+$, based on conjunctival redness and mucous discharge. In agreement with a previous study the patients were clinically divided into a subacute and a
Accepted for publication 10 October 1997 
Table 1. Mononuclear cell infiltration and eosinophil granule proteins in the conjunctiva of patients with ocular cicatricial pemphigoid

\begin{tabular}{|c|c|c|c|}
\hline Antibody & Dilution & Specificity & Source \\
\hline \multicolumn{4}{|c|}{ Mononuclear cell infiltrate: } \\
\hline Anti-CD45 & $1 / 20$ & Common leucocyte antigen & Dako, Hamburg, Germany \\
\hline Anti-CD3 & $1 / 20$ & $\mathrm{~T}$ cell lineage, thymocytes & Dako, Hamburg, Germany \\
\hline Anti-HLA-DR & $1 / 50$ & $\begin{array}{l}\text { HLA-DR (class II } \\
\text { histocompatability antigen) }\end{array}$ & Dako, Hamburg, Germany \\
\hline \multicolumn{4}{|c|}{ Eosinophil granule proteins: } \\
\hline EG1 & $1 / 200$ & ECP (stored and secreted) & Kabi Pharmacia, Uppsala, Sweden \\
\hline EG2 & $1 / 200$ & ECP (secreted), EPX/EDN & Kabi Pharmacia, Uppsala, Sweden \\
\hline BMK-13 & $1 / 50$ & Major basic protein & Biodesign, Dunn, Asbach, Germany \\
\hline
\end{tabular}

$\mathrm{ECP}=$ eosinophil cationic protein EPX = eosinophil protein $\mathrm{X}$ syn; $\mathrm{EDN}=$ eosinophil derived neurotoxin.

chronic disease group. ${ }^{10}$ The clinical course of disease was either chronic, typically with low levels of conjunctival inflammation $(\leqslant 2+)$, or subacute with rapid disease progression within a short course and with an inflammatory activity of $3+$ or more. Conjunctival or corneal epithelial ulcerations have not been seen in any of the patients.

\section{METHODS}

After obtaining informed consent, the conjunctival biopsies were taken by subconjunctival anaesthesia, as published in detail elsewhere. ${ }^{1}$ Tissues were processed for routine histological and immunoperoxidase studies.

Specimens for light microscopy were fixed in Karnovsky's solution ( $1 \%$ paraformaldehyde, $1.25 \%$ glutaraldehyde, $0.13 \%$ sucrose, and 25 $\mathrm{mM}$ sodium phosphate in $0.2 \mathrm{M}$ sodium cacodylate buffer, $\mathrm{pH}$ 7.2), rinsed in cacodylate buffer, dehydrated with ethanol, and embedded in glycol methacrylate (LKB Historesin, LKB Produkter, AB, Bromma, Sweden). Sections of $2 \mu \mathrm{m}$ were stained with standard staining procedures with haematoxylin and eosin and alkaline Giemsa.

For immunohistochemistry, specimens were snap frozen, embedded in Tissue Tek OCT compound (Ames Company, Miles Laboratory, Elkhart, IN, USA) and stored at $-70^{\circ} \mathrm{C}$. Tissues were stained with the avidin-biotinimmunoperoxidase technique. The various primary monoclonal antibodies applied are listed in Table 1. All antibodies were mouse IgG anti-human preparations. ${ }^{18-20}$

Briefly, $4 \mu \mathrm{m}$ cryostat sections were mounted on poly-L lysin (Sigma, Munich, Germany) coated slides. The sections were fixed in acetone and, after incubating with bovine serum albumin (1:20 in PBS) for 20 minutes, the sections were stained with the primary antibodies in a moist chamber at $20^{\circ} \mathrm{C}$ for 20 minutes. The tissue was then blocked for endogenous peroxidase using 3\% hydrogen peroxide in phosphate buffered saline (PBS)

Table 2 Conjunctival histology of patients with ocular cicatricial pemphigoid; subepithelial cell infiltration

\begin{tabular}{lll}
\hline & Chronic $(n=13)$ & Subacute $(n=8)$ \\
\hline Total inflammatory cells & $32.5(19.2)$ & $145.6(43.7)^{\star}$ \\
Neutrophils & $21.5(11.5)$ & $65.4(24.7)^{\star}$ \\
Mast cells & $13.6(2.4)$ & $16.3(4.5)$ \\
Eosinophils & $0(0)$ & $9.2(7.75)^{\star}$ \\
\hline
\end{tabular}

Cell numbers/high power field (450x): mean (SEM).

${ }^{\star} \mathrm{p}<0.001$ by Student's $t$ test comparing subacute and chronic disease. and rinsed with PBS. This was followed by an incubation with a secondary biotinylated rabbit anti-mouse antibody (1:10 in PBS; Dako, Hamburg, Germany) for 20 minutes, and the sections were rinsed in PBS again. Avidinbiotin peroxidase complexes (peroxidase conjugated streptavidin, 1:500; Dako) were applied for 20 minutes. The reactions at sites of binding were developed in peroxidase substrate containing 3-amino-9-ethylcarbazole substrate (Sigma, Munich, Germany) and hydrogen peroxide in $0.1 \mathrm{M}$ acetate buffer. Specimens were then fixed in formalin ( $4 \%$, in acetate buffer), counterstained with Gills No 3 haematoxylin (Sigma), and coverslipped with Aquatex (Merck, Darmstadt, Germany).

All results were independently interpreted by two investigators without knowledge of the patients' identity. Total inflammatory cells, neutrophils, mast cells, and eosinophils were analysed on the haematoxylin and eosin stained slides in the subepithelial layers of the substantia propria. Giemsa staining aided in enumerating the mast cells. The cell numbers per high power field were counted. The significance of the differences in cell numbers from the chronic and the subacute pemphigoid tissues were determined by the unpaired Student's $t$ test.

Cellular and extracellular staining of the eosinophil granule proteins was graded on a scale from 0 to $3+$ in representative high power fields $(\times 450)$ with a $10 \times 10 \mathrm{~mm}$ grid similar to the technique described elsewhere ${ }^{14}$; a $10 \times 2$ $\mathrm{mm}$ grid was used for the epithelial counts. The positive staining was graded as follows: 0 , no staining; $1+$, few foci $(10-30 \%$ of the area) containing light amounts of staining; $2+$, scattered foci $(30-50 \%$ of the area) with intense staining or larger areas ( $\geqslant 50 \%$ of the area) with light staining; $3+$, intensive staining throughout large areas ( $\geqslant 50 \%$ of the area). The significance of differences from the granular protein staining of chronic and subacute inflammation was determined by the MannWhitney U test.

\section{Results}

Cicatricial conjunctivitis was subacute in eight patients and chronic in 13. In all cases, conjunctival inflammation was present at the time of biopsy. The conjunctival biopsies fulfilled the histological and immunohistochemical characteristics of ocular cicatricial pemphigoid. Immunoglobulin and/or 
Table 3 Mononuclear cell infiltration and eosinophil granule proteins in the conjunctiva of cicatricial pemphigoid

\begin{tabular}{|c|c|c|c|c|}
\hline \multirow[b]{2}{*}{ Antibodies } & \multicolumn{2}{|l|}{ Epithelium } & \multicolumn{2}{|l|}{ Subepithelium } \\
\hline & Chronic & Subacute & Chronic & Subacute \\
\hline \multicolumn{5}{|c|}{ Mononuclear cell infitrate $\$:$} \\
\hline CD45 & $27.2(15.8)$ & $39.6(13.7)$ & $48.3(15.4)$ & $62.9(14.3)$ \\
\hline CD3 & $9.7(6.5)$ & $15.6(4.5)$ & $20.3(3.7)$ & $37.2(5.6)^{\star \star}$ \\
\hline HLA-DR & $34.1(9.3)$ & $42.2(14.6)$ & $39.3(6.2)$ & $76.8(11.9)^{\star \star}$ \\
\hline \multicolumn{5}{|c|}{ Human eosinophil granule proteinst: } \\
\hline EG1 & $0.01(0.01)$ & $1.44(0.44)^{\star}$ & $0.13(0.08)$ & $1.75(0.4)^{\star \star}$ \\
\hline EG2 & $0.14(0.06)$ & $0.88(0.2)^{\star}$ & $0.39(1.07)$ & $1.5(0.19)^{\star \star}$ \\
\hline BMK-13 & $0.08(0.08)$ & $0.88(0.38)^{\star}$ & $0.17(0.1)$ & $2.25(0.48)^{\star \star}$ \\
\hline
\end{tabular}

$§$ Cell numbers/high power field (450×); mean (SEM).

†Cellular and extracellular staining within high power field $(\times 450): 0=$ no staining; $1+=$ few foci containing light amounts of staining; $2+=$ scattered foci with intense staining or larger area with light staining; $3+=$ intensive staining throughout large areas. ${ }^{\star} \mathrm{p}<0.05 /{ }^{\star} \mathrm{p}<0.005$ by Mann-Whitney $\mathrm{U}$ test comparing subacute and chronic disease. EG1=antibody directed against stored and secreted eosinophil cationic protein;EG2=antibody directed against secreted eosinophil cationic protein or eosinophil derived neurotoxin; $\mathrm{BMK}-13$ = antibody directed against major basic protein.

complement depositions were found at the epithelial basement membrane of the conjunctiva in all patients included in this study, substantiating the clinical diagnosis of cicatricial pemphigoid. $^{12}$

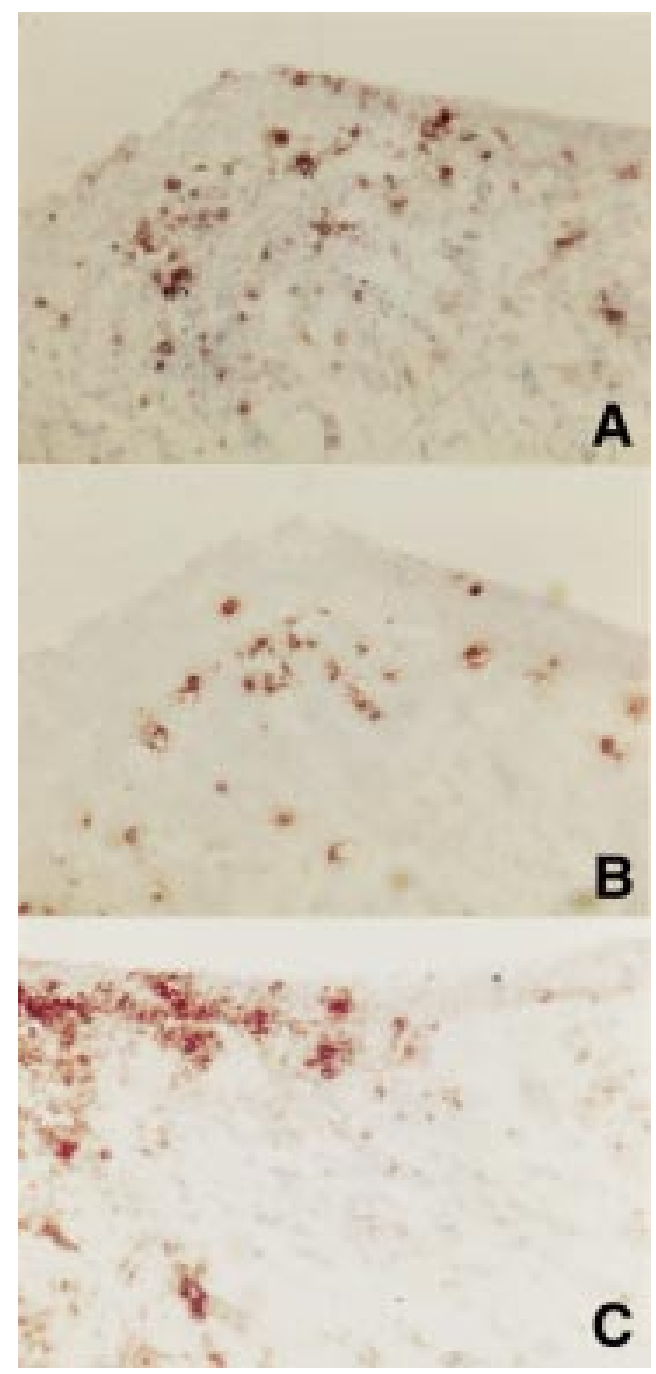

Figure 1 Pattern and location of eosinophil granule proteins in the conjunctival tissue from patients with subacute cicatricial pemphigoid; immunoperoxidase staining $($ magnification $\times 450)$. (A) Eosinophil cationic protein, stored and secreted (EG1 antibody). (B) Eosinophil cationic protein (secreted), eosinophil protein $X$ syn eosinophil derived neurotoxin (EG2 antibody). (C) Major basic protein.
In the patients with chronic conjunctivitis, the mean age was 70.5 years (range 40-92 years); there were nine women and four men. The duration of disease before biopsy was 2 to 13 years (mean 6 (SEM 3.4) years). In the group of patients with subacute conjunctivitis, the mean age was 71.2 years (range 56-86 years); seven were female, one was male. In this second group of patients, the duration of conjunctivitis before biopsy was less than 1 year in six cases, and was 2 years in a further two. Extraocular manifestations were present only in two patients with subacute conjunctivitis. None of the patients had a history of ocular allergies or atopy. All patients were newly diagnosed as cicatricial pemphigoid cases who had never been on immunosuppression. At the time of biopsy, one patient with subacute conjunctivitis was taking azathioprine, one taking oral prednisone, and another taking a nonsteroidal anti-inflammatory drug. Four of these patients received artificial tears, three were using topical antibiotics, and another patient was treated with topical $\beta$ blockers. One patient with chronic conjunctivitis was on dapsone; lubricants were given in nine cases, and antibiotic eyedrops in another four patients.

The results of the histological studies are summarised in Table 2 . The subepithelial infiltration mainly consisted of mononuclear cells and lymphocytes. The number of inflammatory cells was significantly higher in patients with subacute disease than in the others. The subepithelial and perivascular mast cells in patients with subacute disease outnumbered the counts in patients with chronic disease; however, the difference was not statistically significant. Eosinophils were not detected in any of the tissues obtained from patients with chronic cicatricial pemphigoid. In contrast, some eosinophils were found in the substantia propria in five of eight patients with subacute conjunctivitis, but these cells were not detected in the epithelium.

The mononuclear cell infiltrations were counted (Table 3 ) in order to show that the study groups and the subacute and chronic groups of previous publications ${ }^{210}$ are the same. Cells expressing the common leucocyte antigen were found in the epithelium, and were especially abundant in the subepithelium and in close proximity to the vessels. The cell 
numbers in subacute and chronic conjunctivitis did not differ significantly. The subepithelial numbers of $\mathrm{CD} 3+$ cells in patients with subacute disease were significantly higher compared with the chronic disease group. HLA-DR expression within the inflamed tissues was increased in both patients with subacute and chronic cicatricial pemphigoid. However, the highest intensity of class II antigen expression in the subepithelium and at the vessels was detected in patients with subacute disease.

While strongly positive cellular and extracellular staining with antibodies directed against the various eosinophil granular proteins was detected in the tissue sections of patients with subacute OCP, these granular proteins were not found in the tissues of patients with chronic disease (Table 3), or in the conjunctiva obtained from healthy individuals during cataract surgery (data not shown). The staining patterns were both cellular and diffuse in the majority of subacutely inflamed conjunctival specimens. Therefore, enumeration of cells alone was insufficient, and the extracellular staining was also quantified. Staining with the ECP antibodies (EG1 and EG2) in general was less intense than with the antibodies directed against MBP (BMK-13). The eosinophil granule proteins were abundant in the subepithelium and around the vessels; only small amounts of these eosinophil contents were observed in the epithelium (Fig 1).

\section{Discussion}

The pathogenic mechanisms in ocular cicatricial pemphigoid are incompletely understood. Sacks et $a l^{21}$ have shown an abundance of $\mathrm{T}$ cells in chronic cicatricial pemphigoid of the conjunctiva. Rice and Foster $^{2}$ studied the mononuclear cell infiltrate in acute ocular pemphigoid; the subepithelial infiltrate showed significantly increased numbers of $\mathrm{T}$ cells (CD3+, CD5+), $\mathrm{T}$ helper cells (CD4+), T suppressor cells (CD8+), macrophages (CD14+, MAC-1+), and dendritic cells (CD1+, HLA-DR+). The authors suggested that the conjunctival process in cicatricial pemphigoid may develop as a consequence of a primary autoimmune reaction with autoantibodies directed against a $\mathrm{BMZ}$ component. ${ }^{22}$ Bernauer et al ${ }^{10}$ found that the composition of the subepithelial cellular infiltrate varied with the disease activity. Acute disease was characterised by an abundance of macrophages and neutrophils, while the number of $T$ cells was raised in all the disease groups, which is confirmed by our findings. Mast cell participation in ocular cicatricial pemphigoid has been disclosed by Hoang et al. ${ }^{23}$ The total mast cell numbers observed in acute and chronic ocular pemphigoid did not differ significantly, and this corresponds with our observations.

Mast cells, $\mathrm{T}$ cells, macrophages, eosinophils, and fibroblasts apparently interact intimately in the cicatrising conjunctival process. But eosinophils have not been studied in detail in previous studies on OCP conjunctiva. However, complement fixation to tissue bound autoantibodies may lead to infiltration and degranulation of various effector cells, including eosinophils, resulting in tissue injury and clinical inflammation.

After differentiation from a bone marrow derived stem cell, eosinophils migrate into the tissue. Eosinophil degranulation is especially activated by complement factors or immunoglobulins bound to surfaces, ${ }^{24-26}$ features typical of ocular cicatricial pemphigoid. Upon degranulation of the eosinophil, there is a local release of the granular proteins into the surrounding tissue. ${ }^{27}$ The eosinophil specific granules contain enzymes (EPO) and nonenzymatic basophilic proteins (ECP, MBP, EPX/EDN). The eosinophil granule proteins have multiple properties. Besides defence against infections ${ }^{28} 29$ eosinophil granular proteins are toxic to tumour cells and to many mammalian cells ${ }^{24} 3031$ including corneal epithelial cells. ${ }^{32}$ They cause histamine release from basophils and mast cells, and they stimulate neutrophils.

Several findings have linked eosinophils to atopic dermatitis. Major basic protein has been demonstrated in eczematous skin, ${ }^{33}$ and eosinophil cationic protein serum levels are increased in patients with severe atopic dermatitis. ${ }^{34}$ Whereas eosinophils can be easily detected histologically in tissue by their characteristic granules, they are undetectable by classic staining after degranulation. It is interesting to note that eosinophils have not been found histologically in the cutaneous lesions from patients with chronic atopic dermatitis. However, significant accumulation of MBP and EDN/EPX has been detected by immunohistochemical techniques, supporting the concept of degranulation of eosinophils in the inflammatory lesions. ${ }^{33} 35$ Typically, within 2-8 hours after topical provocation with allergens, significant immigration with eosinophils is detected in the skin; mononuclear infiltration dominates after 24 hours, when most eosinophils have already degranulated and are histologically undetectable. ${ }^{36}$ Deposition of granule proteins in the tissue is related to the disease activity in atopic dermatitis. Similar observations have been made in bronchial asthma. While eosinophils are not detected in the inflamed tissue, their granular contents have been demonstrated by electron microscopy and immunohistochemistry. ${ }^{37}$ The secretion of granule proteins from blood eosinophils is increased in asthmatics, ${ }^{38}$ significantly parallels disease activity, and returns to normal with immunotherapy. ${ }^{39}$ Taken together, these findings provide evidence that eosinophils may play an important role in the propagation of inflammatory reactions including, perhaps, ocular cicatricial pemphigoid, as the findings in this report suggest.

Significant eosinophil invasion of the skin has been demonstrated in bullous pemphigoid and pemphigus vulgaris. ${ }^{40}{ }^{41}$ It has been suggested that activated eosinophils, releasing their granular products may be of importance for blister formation in bullous pemphigoid. ${ }^{15}$ The release of proteolytic enzymes of eosinophils to the lamina lucida in bullous pemphigoid, found by electron microscopy and immunohistochemistry, ${ }^{42}$ is believed to play a pathogenic role 
during the initial stages of blister formation. We speculate that the contribution of eosinophils to the tissue damage in ocular cicatricial pemphigoid is greater than expected from previous immunopathological studies. Eosinophils are scanty in the conjunctival specimens by light microscopy. ${ }^{16}$ Yet, our studies clearly demonstrated that significant amounts of eosinophil granule proteins are released into the highly inflamed conjunctival tissue in patients with subacute ocular cicatricial pemphigoid. It may be postulated that eosinophils migrate into the conjunctiva in the very early stage of OCP conjunctival lesions. Eosinophils, by their proinflammatory activity, may contribute to the amplification of mononuclear infiltration, seen in this and many previous studies. Eosinophils and eosinophil granule proteins, by their toxic effects to the epithelial cells, may eventually lead to the epitheliopathy ${ }^{32}$ developing in patients with ocular cicatricial pemphigoid. However, epithelial lesions were not found in any of the patients studied here.

An association between eosinophils and fibrosis is supported by numerous observations; by the elevated levels of MBP detected in patients with systemic sclerosis, by eosinophilia found with diffuse fasciitis, by the relation between eosinophilia or eosinophil degranulation with fibrosis detected by clinicopathological studies, and by the expression of transforming growth factors by eosinophils found during wound healing. ${ }^{43-47}$ Eosinophils and eosinophil granule proteins may also be involved in the cicatrising process in OCP; however, eosinophil granular contents were not found in the conjunctival specimens from our patients with chronic disease.

Since our studies suggested that eosinophils may be involved in the early stages of the inflammatory cascades in ocular cicatricial pemphigoid, anti-inflammatory medication effective against these cells might exert a beneficial effect if employed early in the course of the disease. The activation and effector functions of eosinophils can be impaired by cyclophosphamide and corticosteroids. Our findings thus provide a rationale and support for the empirical observations of the superiority of broad spectrum, rather than cell specific immunosuppressive drugs, such as cyclosporin A. This is in agreement with previous therapeutic suggestions by others. ${ }^{61048} 49$

We are indebted to Mrs S Schindler for her excellent technical assistance.

1 Foster CS. Cicatricial pemphigoid. Trans Am Ophthalmol Soc 1986;84:527-663.

2 Rice BA, Foster CS. Immunopathology of cicatricial pemphigoid affecting the conjunctiva. Ophthalmology 1990; 97:1476-83.

3 Mondino BJ. Bullous diseases of the skin and mucous membranes. In: Tasman W, Jaeger EA, eds. Duane's clinical oph thalmology. Revised ed. Philadelphia: JB Lippincott, 1992, vol 4, chapter 12 .

4 Mondino BJ. Cicatricial pemphigoid and erythema multiforme. Ophthalmology 1990;97:939-52.

5 Foster CS, Wilson LA, Ekins MB. Immunosuppressive therapy for progressive ocular cicatricial pemphigoid. $O p h-$ thalmology 1982;89:340-53.

6 Mondino BJ, Brown SI. Immunosuppressive therapy in Mondino BJ, Brown SI. Immunosuppressive therapy in 453-9.

7 Tauber J, Sainz de la Maza M, Foster CS. Systemic chemotherapy for ocular cicatricial pemphigoid. Cornea 1991;10: 185-95.
8 Leonard JN, Hobday CM, Hafferden GP. Immunofluorescent studies in ocular cicatricial pemphigoid. Br f Dermatol cent studies in ocular

9 Ahmed AR, Foster CS, Zaltas M, et al. Association of DQw7 DQB1 $\left.{ }^{\star} 0301\right)$ with ocular cicatricial pemphigoid. Proc Natl Acad Sci USA 1991;88:11579-82.

10 Bernauer W, Wright P, Dart JK, Leonard JN, Lightman S. The conjunctiva in acute and chronic mucous membrane pemphigoid. An immunhistochemical analysis. Ophthalmology 1993;100:339-46.

11 Trocme SD, Kephart GM, Allansmith MR, Bourne WM, Gleich GJ. Conjunctival deposition of eosinophil granule major basic protein in vernal keratoconjunctivitis and contact lens-associated giant papillary conjunctivitis. $\mathrm{Am} \mathcal{f}$ Ophthalmol 1989;108:57-63.

12 Trocme SD, Bartley GB, Campbell RJ, et al. Eosinophil and neutrophil degranulation in ophthalmic lesions of Wegener's granulomatosis. Arch Ophthalmol 1991;109:1585-9.

13 Trocme SD, Kephart GM, Bourne WM, Buckley RJ, Gleich GJ. Eosinophil granule major basic protein deposition in corneal ulcers associated with vernal keratoconjunctivitis. Am f Ophthalmol 1993;115:640-3.

14 Trocme SD, Aldave AJ. The eye and the eosinophil. Surv Ophthalmol 1994; 39:241-52.

15 Czech W, Schaller J, Schöpf E, Kapp A. Granulocyte activation in bullous diseases: release of granular proteins in bulous pemphigoid and pemphigus vulgaris. $\mathcal{f}$ Am Acad Dermatol 1993;29:210-5.

16 Norn MS, Kristensen EB. Benign mucous membrane pemphigoid. II Cytology. Acta Ophthalmol 1974;52:282-90.

17 Mondino BJ, Brown SI. Ocular cicatricial pemphigoid. Ophthalmology 1981;88:95-100.

18 Tai PC, Spry CJF, Peterson C, Venge P, Olsson J. Monoconal antibodies distinguish between storage and secreted forms of eosinophil cationic protein. Nature 1984;309:182-4.

19 Mason DY, Sammons R. Alkaline phosphatase and Mason DY, Sammons R. Alkaline phosphatase and
peroxidase for double immunoenzymatic labelling of celluperoxidase for double immunoenzymatic labelling

20 Barkans JR, Mogbel R, Bradley B, Fraw AJ, Kay AB. Immunohistological comparison of an anti-MBP monoclonal antibody (mAb) with other anti eosinophil antibodies. Clin Exp Allergy 1990;20(suppl 1):1.

21 Sacks EH, Jacobiec FA, Wieczorek R, et al. Immunophenotypic analysis of the inflammatory infiltrate in ocular cicatricial pemphigoid. Further evidence for a $\mathrm{T}$ cell mediated disease. Ophthalmology 1989;96:236-43.

22 Roat MI, Alstadt SP, Carpenter AB, et al. Antibasement membrane antibody-mediated experimental conjunctivitis. Invest Ophthalmol Vis Sci 1990;31:168-75.

23 Hoang-Xuan T, Foster CS, Raizman MB, Greenwood B. Mast cells in conjunctiva affected by cicatricial pemphigoid. Ophthalmology 1989;96:1110-4.

24 Gleich JG, Adolphson CR. The eosinophil leukocyte: structure and function. Adv Immunol 1986;39:177-253.

25 Kapp A, Zeck-Kapp G, Czech W, Schöpf E. The chemokine RANTES is more than a chemoattractant: characterization of its effect on human eosinophil oxidative metabolism and morphology in comparison with IL-5 and GM-CSF. $\mathcal{F}$ Invest Dermatol 1994;102:906-14

26 Das AM, Williams TJ, Lobb R, Nourshargh S. Lung eosinophilia is dependent on IL-5 and the adhesion molecules CD18 and VLA-4, in a guinea-pig model. Immunology 1995;84:41-6.

27 Samoszuk M, Sholly S, Epstein AL. Eosinophil peroxidase is detectable with a monoclonal antibody in collagen bands of nodular sclerosis in Hodgkin's disease. Lab Invest 1987; 56:394-400.

28 Venge P, Strömberg A, Braconier JH, Roxin LE, Olsson I. Neutrophil and eosinophil graanulocytes in bacterial infection: sequential studies of cellular and serum levels of infection: sequential studies of cellular and serum

29 Zuker-Franklin D. Eosinophil function and disorders. $A d v$ Intern Med 1974;19:1-25.

30 Young JDE, Peterson CGB, Venge P, Cohn ZA. Mechanism of membrane damage mediated by human eosinophil cationic protein. Nature 1986;321:613-6.

31 Frigas E, Loegering DA, Gleich GJ. Cytotoxic effects of the guinea pig eosinophil major basic protein on tracheal epithelium. Lab Invest 1980;42:35-43.

32 Trocme SD, Gleich GJ, Kephart GM, Zieske JD. Eosinophil granule major basic protein inhibition of corneal epithelial wound healing. Invest Ophthalmol Vis Sci 1994;35:3051-4.

33 Leiferman KM, Ackerman SJ, Sampson HA, et al. Dermal deposition of eosinophil-granule major basic protein in atopic dermatitis. Comparison with onchocerciasis. $N$ Engl f Med 1985;313:282-5.

34 Kapp A, Czech W, Krutmann J, Schöpf E. Eosinophil cationic protein in sera of patients with atopic dermatitis. $f \mathrm{Am}$ Acad Dermatol 1991;24:555-8.

35 Leiferman KM. Eosinophils in atopic dermatitis. Allergy 1989;44(suppl 9): 20-6.

36 Charlesworth EN, Hood AF, Soter NA, et al. Cutaneous latephase response to allergen. $\mathcal{F}$ Clin Invest 1989;83:1519-29.

37 Bousquet J, Chanez P, Lacoste JY, et al. Eosinophilic inflammation in asthma. N Engl F Med 1990;323:1033-9.

38 Carlson M, Hakansson L, Peterson C, Stalenheim G, Venge P. Secretion of granule proteins from eosinophils and neutrophils is increased in asthma. $\mathcal{F}$ Allergy Clin Immunol 1991;87:27-33.

39 Rak S, Björnson A, Hakanson L, Sörenson S, Venge P. The effect of immunotherapy on eosinophil accumulation and production of eosinophil chemotactic activity in the lung of production of eosinophil chemotactic activity in the lung of
subjects with asthma duri ng natural pollen exposure. $\mathfrak{f}$ Allergy Clin Immunol 1991;88:878-88. 
40 Jordan RE, Kawana S, Fritz KA. Immunopathologic mechanisms in pemphigus and bullous pemphigoid. $\mathcal{F}$ Invest Dermatol 1985;85(Suppl 1):72-8.

41 Schaller J, Niedecken HW, Biwer E, et al. Charakterisierung lymphozytärer Infiltratzellen bei bullösem Pemphigoid und Pemphigus vulgaris. Dermatol Monatschr 1990;176:661-8. 42 Dubertret L, Bertaux B, Fosse M, Touraine R. Cellular Br F Dermatol 1980;104:615-24.

43 Cox D, Earle L, Jimenez SA, Leiferman KM, Gleich GJ, Varga J. Elevated levels of eosinophil major basic protein in the sera of patients with systemic sclerosis. Arthritis Rheum 1995;7:939-45.

44 Moutsopoulos HM, Webber BL, Paulidis NA, et al. Diffusefasciitis with eosinophilia: a clinicopathologic study. $A m \mathcal{F}$ Med 1980;68:701-9.
45 Noguchi H, Kephart G, Campbell J, et al. Tissue eosinophilia and eosinophil degranulation in orbital eosinophilia and eosinophil degranulation
pseudotumor. Ophthalmology 1991;98:928-32.

pseudotumor. Ophthalmology 1991;98:928-32.
46 Noguchi H, Kephart GM, Colby TV, Gleich GJ. Tissue eosinophilia and eosinophil degranulation in syndromes associated with fibrosis. Am f Pathol 1992;140:521-8.

47 Wong DTW, Donoff RB, Yang J, et al. Sequential expression of transforming growth factors $\alpha$ and $\beta 1$ by eosinophils during cutaneous wound healing in the hamster. $A m \mathcal{F}$ Pathol 1993;143:130-42.

48 Mondino BJ, Brown SI, Lempert S, Jenkins MS. The acute manifestations of ocular cicatricial pemphigoid: diagnosis and treatment. Ophthalmology 1979;86:543-52.

49 Elder MJ, Lightman S, Dart JKG. Role of cyclophosphamide and high dose steroid in ocular cicatricial pemphigoid. Br f Ophthalmol 1995;79:264-6. 